\title{
Improving flood damage assessment models in Italy
}

\author{
Mattia Amadio ${ }^{1}$ Jaroslav Mysiak ${ }^{1} \cdot$ Lorenzo Carrera $^{1}$. \\ Elco Koks ${ }^{2}$
}

Received: 4 September 2015/ Accepted: 4 March 2016/Published online: 23 March 2016

(C) The Author(s) 2016. This article is published with open access at Springerlink.com

\begin{abstract}
Flood damage assessments are often based on stage-damage curve (SDC) models that estimate economic damage as a function of flood characteristics (typically flood depths) and land use. SDCs are developed through a site-specific analysis, but are rarely adjusted to economic circumstances in areas to which they are applied. In Italy, assessments confide in SDC models developed elsewhere, even if empirical damage reports are collected after every major flood event. In this paper, we have tested, adapted and extended an up-to-date SDC model using flood records from Northern Italy. The model calibration is underpinned by empirical data from compensation records. Our analysis takes into account both damage to physical assets and losses due to foregone production, the latter being measured amidst the spatially distributed gross added value.
\end{abstract}

Keywords Flood risk management - Stage depth-damage curves · Economic damage · Disaster losses · Italy

\section{Introduction}

The EU Floods Directive (FD, 2007/60/EC) manifested a shift of emphasis away from a structural defence approach to a more holistic risk management, with structural and nonstructural measures having the same importance. The FD compels the identification of areas exposed to flood hazard and risk, and the adoption of measures to moderate flood impacts. A sound, evidence-based risk assessment should underpin public disaster risk reduction and territorial development policies. Stage-damage curves (SDCs) are a

Elco Koks

elco.koks@vu.nl

Fondazione Eni Enrico Mattei, Venice, Italy

2 Institute for Environmental Studies (IVM), VU University Amsterdam, Amsterdam,

The Netherlands 
customary tool used for assessing risks arising from the physical disruption of physical tangible assets (Genovese 2006; Messner et al. 2007; Thieken et al. 2009; Jongman et al. 2012), typically as a function of flood characteristics (primary water depth, in some cases speed and persistence) over different land use (LU) categories (Messner et al. 2007; Merz et al. 2010). SDCs are either empirically determined from observed damage events or inferred from bibliographic sources. Most flood risk assessment studies employ empirical SDC models that are developed elsewhere and neither tested nor calibrated for the specific study area (Sargent 2013). The lack of practical corroboration compromises the reliability of the model results. In addition, the SDC models are afflicted by substantial uncertainties stemming from the variability of assets value and vulnerability (Messner et al. 2007; Merz et al. 2010; De Moel and Aerts 2011). To some extent, these uncertainties can be reduced if the damage models are designed to reproduce the economic conditions of households and businesses (Luino et al. 2009; De Moel and Aerts 2011). Different SDC models have been reported in the literature, but most of them have been developed for site-specific application and are rarely tested for transferability. SDCs based on empirical material from Italy are rare (Molinari et al. 2013; Scorzini and Frank 2015). This is so despite the common practice of state compensation for household (private) losses, for which certified damage reports are collected. In addition, the SDC models often assume that the potential damage is constant throughout the year. This does not hold true for agricultural land, where crop value varies depending on crop maturity. Furthermore, SDC models address physical assets damage and hence are not able to determine output losses in terms of foregone production that arises from impairment of economic activities until after the production process is fully recovered. Spatially distributed economic and social variables such as population density and GDP can help to estimate the impact on the economic flow from natural hazards. Different methodologies are employed for this purpose, such as econometric models (Cavallo et al. 2012), input-output (IO) models (Hallegatte 2008; Koks et al. 2014) and computable general equilibrium (CGE) models (Bosello et al. 2012; Rose and Wei 2013; Carrera et al. 2015). These are useful for estimating the impact of a hazard on the economy up to the regional level, but require disaggregated data that are rarely available at lower scales. The availability of sound flood risk models appropriate for the Italian economic and social circumstances is essential for well-designed and informed flood risk management policies. In this paper, we explore ways to improve the damage and loss assessments for the sake of a better risk assessment and management. Methods such as those explored in this paper have been tested elsewhere at national (Winsemius et al. 2013) and international levels (Ward et al. 2013).

The paper is structured as follows. First, we test the applicability and transferability of up-to-date SDCs against household damage declarations in the aftermath of the 2014 Modena flood in the Emilia-Romagna region. Subsequently, we describe a detailed cropspecific model for agricultural losses, better suitable for compensation claims. Ultimately, we explore the use of gross value added (GVA) as an indicator of exposure for production losses (Peduzzi et al. 2009).

\section{Materials and methods}

Most commonly, flood risk $\mathbf{R}$ is determined as a function of hazard probability (H), exposure $(\mathbf{E})$ and vulnerability $(\mathbf{V}): \boldsymbol{R}=\boldsymbol{H} \times \boldsymbol{E} \times \boldsymbol{V}$ (Crichton 1999; Kron 2005; Messner et al. 2007; Barredo and Engelen 2010). Hazard is expressed as observed or modelled 
probability $\boldsymbol{p}$ of river discharges exceeding the holding capacity of river embankments. Exposure is the depreciated or replacement value of the tangible physical assets in hazardprone areas. Vulnerability is the susceptibility to damage under different levels of flood submersion. The structural damage to physical tangible assets is also termed direct impact or damage on stock (Merz et al. 2010; Meyer et al. 2013). When productive capital is damaged, the impacts can also be evaluated in terms of production losses or foregone flows of production. Sometimes, flow losses are equated to indirect impacts or damage. This is misleading because production losses are an alternative manifestation of material damage to productive capital assets, one that contemplates the value of output (goods and services) that would have been produced during the time of suspended production, rather than the depreciated value of the damaged assets. Flow losses are able to capture situations in which production is disrupted as a result of dearth of critical input with no material damage to productive capital, for example in the case of lifeline disruption (Przyluski and Hallegatte 2011). Here we avoid this ambiguity by referring to damage in terms of partial or total physical asset destruction and losses in terms of foregone production flows. This is consistent with economic theory, according to which the value of a stock is the discounted flow of net future returns from its operation (Rose 2004). We estimate flood damage both as asset damage, by using the SDC model, and as production losses in terms of affected annual GVA (Fig. 1). Agricultural losses are estimated by using a complementary model that accounts for crop production cost and the value of yields (Thieken et al. 2009).

\subsection{SDC models for asset damage}

Among the SDC models found in the literature, two have been found performing reasonably well as compared to reported empirical damage in Italy (Scorzini and Frank 2015):

ASSET DAMAGE

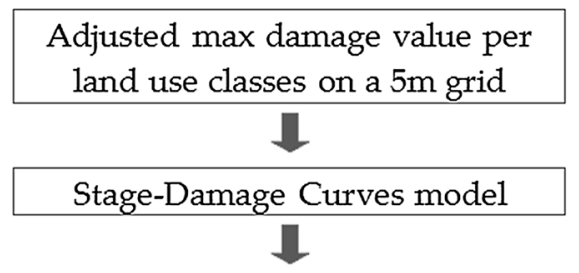

PRODUCTION LOSSES

Spatial distribution of GVA on a $250 \mathrm{~m}$ grid

Stage-Impact Curve model

Flood depth simulation for analysed event (Secchia 2014)

\begin{tabular}{|c|c|}
\hline Damage as share of max LU value & Loss as share of GVA value \\
\hline $\begin{array}{c}\text { Comparison with empirical } \\
\text { damage data }\end{array}$ & $\begin{array}{c}\text { Evaluation of exposed } \\
\text { agricultural production }\end{array}$ \\
\hline $\begin{array}{c}\text { Adjustment of SDC and max } \\
\text { values }\end{array}$ & $\begin{array}{c}\text { Time-dependent evaluation of } \\
\text { agricultural losses }\end{array}$ \\
\hline
\end{tabular}

Fig. 1 Flood damage assessment methodological approach 
Damage Scanner (DS or SDC-1) (Klijn et al. 2007) and JRC (SDC-2) (Huizinga 2007). SDC-1 has been recently updated (De Moel et al. 2013, 2014; Koks et al. 2014) with additional subclasses for residential, rural and industrial damage (Sluijs et al. 2000). This set estimates impacts on building surfaces separately from other sealed areas such roads. In contrast, SDC-2 aggregates the impacts on mixed land use classes: the maximum value for each of these main classes is calculated over the weighted sum of buildings and area, including both their structure and content. This approach is adapted to work in conjunction with low-resolution land use maps such CLC. Depth resolution also varies among the two sets: SDC- 1 takes steps of $0.1 \mathrm{~m}$, while the other set has $0.5 \mathrm{~m}$ steps. All these curves are based on expert judgment and none of them has been validated on empirical damage records. SDC-1 and SDC-2 are selected as the best available options to date for transferability testing. We employ detailed regional land use data combined with the description and location of buildings extracted from the regional spatial development plans (RER 2011). The LU classification is the same as in CORINE Land Cover (EEA 2006), but includes an additional, more detailed and accurate disaggregation level. The damage is estimated for sealed areas and agricultural land, while roads and natural areas are not considered. For residential damage, we consider both the damage to the physical structure of buildings and to their associated content. The model also accounts for damage to passenger vehicles based on average prices from statistical registers (ACI 2014).

With this proposed methodology, we aim to simulate the impact of the flood event which struck the Province of Modena in 2014. On January 19, an 80-m-wide levee breach occurred on the Secchia River, which caused a spillage of 200 cubic metres per second in the surrounding countryside, covering nearly 6.5 thousand ha of cultivated land (Fig. 2). Seven municipalities were affected, above all the small towns of Bastiglia and Bomporto, which were flooded for more than $48 \mathrm{~h}$. The total volume of water pumped out of the inundated area was estimated to exceed 20 million cubic metres (Fotia 2014).

For the purpose of this paper, we have used the hydrological simulation of the event produced by D'Alpaos et al. (2014). The extent of the simulated flood is nearly five thousand hectares, with an average depth of 1 metre. The damage estimated through SDC is compared to household-declared damage made available by local authorities, while damage to business activity will be made available later. The damage reports distinguish between structure, mobile goods (furniture and common domestic appliances) and registered vehicles (private cars and motorcycles).

\subsection{Agricultural losses}

Expected losses in sparsely populated rural areas are often substantially lower than those in residential areas, since the density of exposed value is lower. For this reason, agricultural damage is often neglected or accounted for by using simple approaches with coarse estimates. Yet a thorough loss assessment is necessary in areas where agricultural production is the predominant activity (Messner et al. 2007), as it determines compensation where compelled by liability or granted in the form of state aid (Forster et al. 2008; Tapia-Silva et al. 2011; Twining 2014). Standard SDC models are suboptimal for this purpose as they are not equipped to account for the variety in cultivated crops values, yields and the progressive distribution of production costs. The SDC typically assumes a constant economic value throughout the year, which is not consistent with the fact that the damage depends on a flood occurrence (Ward et al. 2013). In our enhanced model, we determine the representative full crop damage per hectare $D_{\mathrm{MAX}}$ as a weighted average of all major 


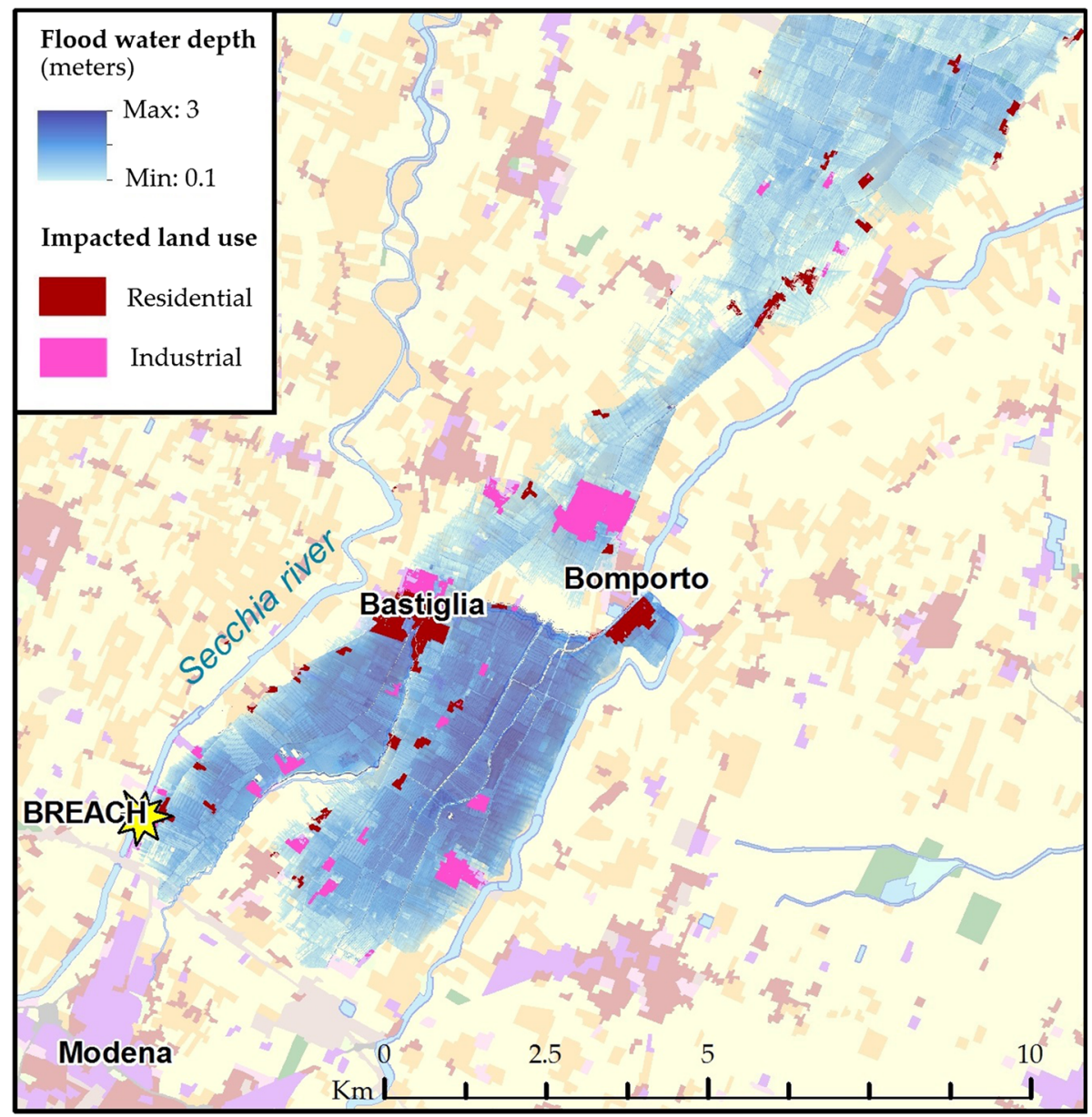

Fig. 2 Simulated max flood depth ensuing from the Secchia levee breach in January 2014 near Modena. Impacted areas are highlighted for residential and industrial land use

crop values in the analysed area (Eq. 1) at any time during the growing session (Eqs. 2 and 3).

$$
D_{\mathrm{MAX}}=\sum_{i=1}^{n} P_{i} \times Y_{i} \times \frac{\mathrm{UAA}_{i}}{\mathrm{UAA}}
$$

where $\boldsymbol{i}$ denotes crop index, $\boldsymbol{P}$ the producer prices (per tonnes), $\boldsymbol{Y}$ the yield (in tonnes/ hectare) and UAA the utilised agricultural area. ${ }^{1}$

$D_{\text {MAX }}$ at any time $t$ during the growing season can be estimated either by taking into account the end-of-season yield and producer price of crop $i$ minus production costs not exerted until the end of the production cycle (Eq. 3), or as a sum of all production costs

\footnotetext{
${ }^{1}$ UUA comprises the total area of arable land, permanent crops and meadows.
} 
exerted from the beginning of the growing season up to the damage event plus the land rent (Eq. 4). The best estimate of crop value at harvest time is gross saleable product ${ }^{2}$ (GSP).

$$
D_{\mathrm{MAX}}^{t}=\sum_{i=1}^{n}\left(\left[\mathrm{GSP}_{i}-\sum_{t}^{\mathrm{End}} \mathrm{DC}_{i}\right] \times \frac{\mathrm{UAA}_{i}}{\mathrm{UAA}}\right)
$$

where DC is the direct production costs ${ }^{3}$ and $t$ a defined moment of the production cycle $(0<t<$ End $)$.

$$
D_{\mathrm{MAX}}^{t}=\sum_{i=1}^{n}\left(\left[\mathrm{TNI}_{i}+\sum_{0}^{t} \mathrm{DC}_{i}\right] \times \frac{\mathrm{UAA}_{i}}{\mathrm{UAA}}\right)
$$

where TNI is total net income calculated on the previous years' average and DC a sum of crop-specific production costs exerted up to the damage event.

The average yield, production cost and net income per hectare of arable and permanent crops are determined for different cultivation patterns in the Emilia-Romagna administrative region (RER), based on empirical observations (Altamura et al. 2013). The direct cost is calculated as a function of the average cost of technical means (raw materials, machinery) and labour per hectare. Costs are distributed across the production year on the basis of the life cycle of each crop as shown in Fig. 3.

A field analysis conducted after the event (Setti 2014) highlighted that the flood occurred at a time when many field crops had not yet been planted. Wheat and alfalfa were the most commonly exposed crops, but the only physical harm reported was some occasional yellowing among crop fields. Vineyards and other permanent crops were in vegetative rest and apparently did not suffer any damage. In the end, the report on regional agricultural production for the year 2014 (OAA-RER 2014) has not revealed any substantial yield reduction. On the contrary, the average yields per hectare in 2014 were slightly higher than in 2013.

\subsection{Gross value added model for production losses}

To estimate the production losses, we use gridded gross value added (GVA) (Peduzzi et al. 2009; Green et al. 2011) based on the statistical disaggregation of GVA at the labour

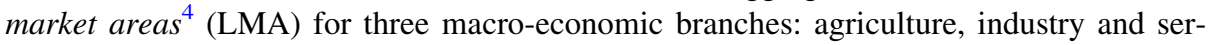
vices (ISTAT 2013). We assume that within the LMAs the GVA is uniformly spread, but only over the land use classes ascribed to each specific branch of economic activities. In the case of agriculture and industry, the GVA is attributed, respectively, to the UAA and the total industrial area distinguishable in the land use/cover data sets. The GVA generated by services is distributed proportionally to the population density. The assumption behind this is that since services are multiple and dispersed, they are proportional to the number of residents served. A population density grid is produced based on the 2011 census tracks (ISTAT 2011) with a cell resolution of 250 metres. The expected losses as a share of GVA per cell are then calculated by means of a step function (Eq. 4; Fig. 4) (Carrera et al. 2015),

\footnotetext{
2 The average gross income from the sale of the yield expressed in $€ /$ ha, not inclusive of direct costs.

3 Sum of the costs for technical means and labour, excluding subsidies.

${ }^{4}$ Labour Market Areas (in Italian Sistemi Locali di Lavoro, SLL) have been devised by the Italian Statistical Bureau as continuous territorial areas in which most of the daily work activity of the resident population takes place. Typically, a LMA is smaller than a NUTS3 unit and larger than a municipality.
} 


\begin{tabular}{|c|c|c|c|c|c|c|c|c|c|c|c|c|c|c|c|}
\hline & \multicolumn{13}{|c|}{ Growing season months } & \multicolumn{2}{|l|}{ Period } \\
\hline & OCT & NOV & $\mathrm{DEC}$ & JAN & FEB & MAR & APR & MAY & JUN & JUL & AUG & SEP & 1 & sow & $50 \%$ \\
\hline Wheat & 1 & 1 & 2 & 2 & 2 & 2 & 2 & 2 & 3 & 4 & 4 & 4 & 2 & growth & $30 \%$ \\
\hline Maize & 3 & 4 & 4 & 4 & 4 & 4 & 1 & 1 & 1 & 2 & 2 & 3 & 3 & harvest & $20 \%$ \\
\hline Alfalfa & 2 & 2 & 2 & 2 & 2 & 1 & 1 & 2 & 2 & 2 & 2 & 2 & 4 & renewal & $0 \%$ \\
\hline
\end{tabular}

Fig. 3 Allocation of production cost and the typical growing season for the most common cereal crops in the study area

Fig. 4 Stage-impact curve for GVA losses

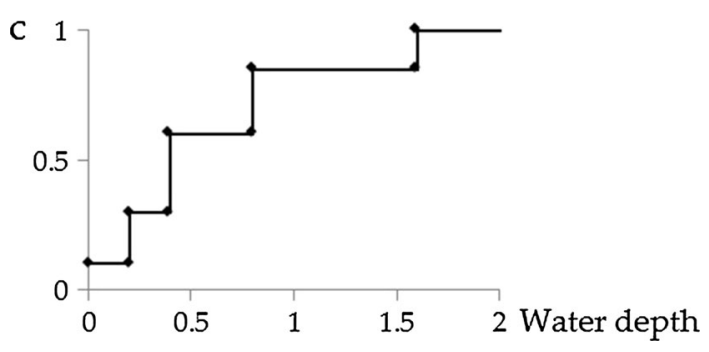

inspired by the literature on flood damage functions (De Moel and Aerts 2011; De Moel et al. 2012; Jongman et al. 2012; Saint-Geours et al. 2014). The curve assumes that the higher the water level, the more persistent is the productivity loss. This assumption is based on three principles: (a) higher water depths cause larger productive asset damage; (b) larger asset damage typically requires longer recovery periods; and (c) flood water retreat is a function of flood depth. The relationship between water depth and persistence of the impact is likely afflicted by uncertainty; however, we assume that the curve is suited for test purposes.

$$
\text { Impact on } \mathrm{GVA}_{S, L}=\sum_{k=1}^{n} \mathrm{FC}_{S, L_{k}} \times c_{k}
$$

where FC is the flooded cell $k$, and $c$ is the damage factor applied to each $\mathrm{FC}_{k}$ based on its water depth. $N$ is the number of cells belonging to sector $S$ for each system $L$.

\section{Results}

\subsection{Asset losses}

The damage assessment carried out on the Modena flood by means of the two selected SDC models (SDC-1 and SDC-2) yields values that differ by 170 million, corresponding to one-third of the SDC-2 estimate (Fig. 5, left). Besides, there is a sizeable divergence in the distribution of the estimated damage across the land use categories. The SDC- 1 yields a damage that is more than two times higher than the SDC-2 output for the industrial land use category. On the contrary, the SDC- 1 estimated damage is lower than the SDC- 2 by a factor 0.7 for the residential land use category and only one-fifth for the rural category.

Overall, the SDC-1 overestimates declared damage in residential areas by a factor 4.5 , but for the urban spaces outside of buildings this difference peaks to a factor of 9.2. The SDC-2 results are even larger, 13 times greater than those observed. The damage shares 

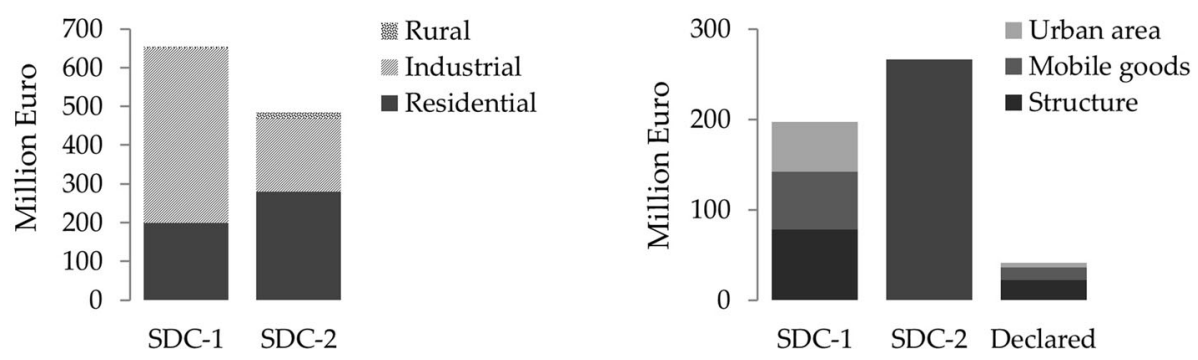

Fig. 5 (left) Output of the damage model for the 2014 flood event among aggregated land uses; (right) comparison of SDC models output for urban areas against registered compensation requests from households

between structure, mobile goods and private vehicles simulated by SDC- 1 resemble ${ }^{5}$ the ratios of declared damage (Fig. 5, right). For the calibration exercise, we have chosen SDC-1 over SDC-2 because it is able to disaggregate structural and content damage in isolated dwellings and built-up areas. Both estimated and declared damage are geocoded and aggregated into a $250 \mathrm{~m}$ grid.

The calibration is carried out only on matching cells by means of regression analysis under the hypothesis of linear relationship. There are 61 (out of 157) matching cells between simulated and empirical damage, which is less than $40 \%$ in terms of affected area, but the matching cells account for $83 \%$ of simulated and $75 \%$ of the declared damage. As shown in Fig. 6, this mismatch is caused mainly by uncertainty in the land use data for sparsely developed areas and in the extent of the flood boundaries, but the core damage areas of Bastiglia and Bomporto are well matched for recorded and simulated damage. For each land use category, the maximum damage value is individually adjusted by using the $B$ (slope) coefficients as scaling factor. Figure 7 shows the results of linear regression between SDC-1 output and empirical damage before and after calibration for total (A), structural (B) and content (C) damage categories.

The pre-calibration output overestimated the total damage in residential areas by a factor 4.5-7, depending on the within-urban land use category. The calibrated damage values are regressed with good results in terms of the observed/reported damage (Rsquared is 0.8 ) for all categories except for urban area, where registered vehicles are assumed to be homogeneously distributed. This proved to be an over simplistic assumption. For building structure and content, the coefficient $(B)$ is close to 1.0, and the final output overestimates recorded residential damage by just $6 \%$ (Table 1 ).

\subsection{Agricultural losses}

The flood extent comprises predominately rural areas $\left(43 \mathrm{~km}^{2}\right)$, with a prevalent share of arable crops ( $81 \%$ of UUA). The typical crops include cereals, in particular soft wheat and maize ( $40 \%$ of arable crops) and forage (52\% of arable crops). Other arable crops together cover less than $8 \%$. Vineyards and other permanent crops cover the remaining $19 \%$ of UAA. As shown in Fig. 3, in January maize crops are fallow, while wheat is in its vegetative stage. This means that just half of cereal production is affected. Losses for

${ }^{5}$ Simulated damage: 57/33/10 \%. Declared damage: 60/35/5\%. 


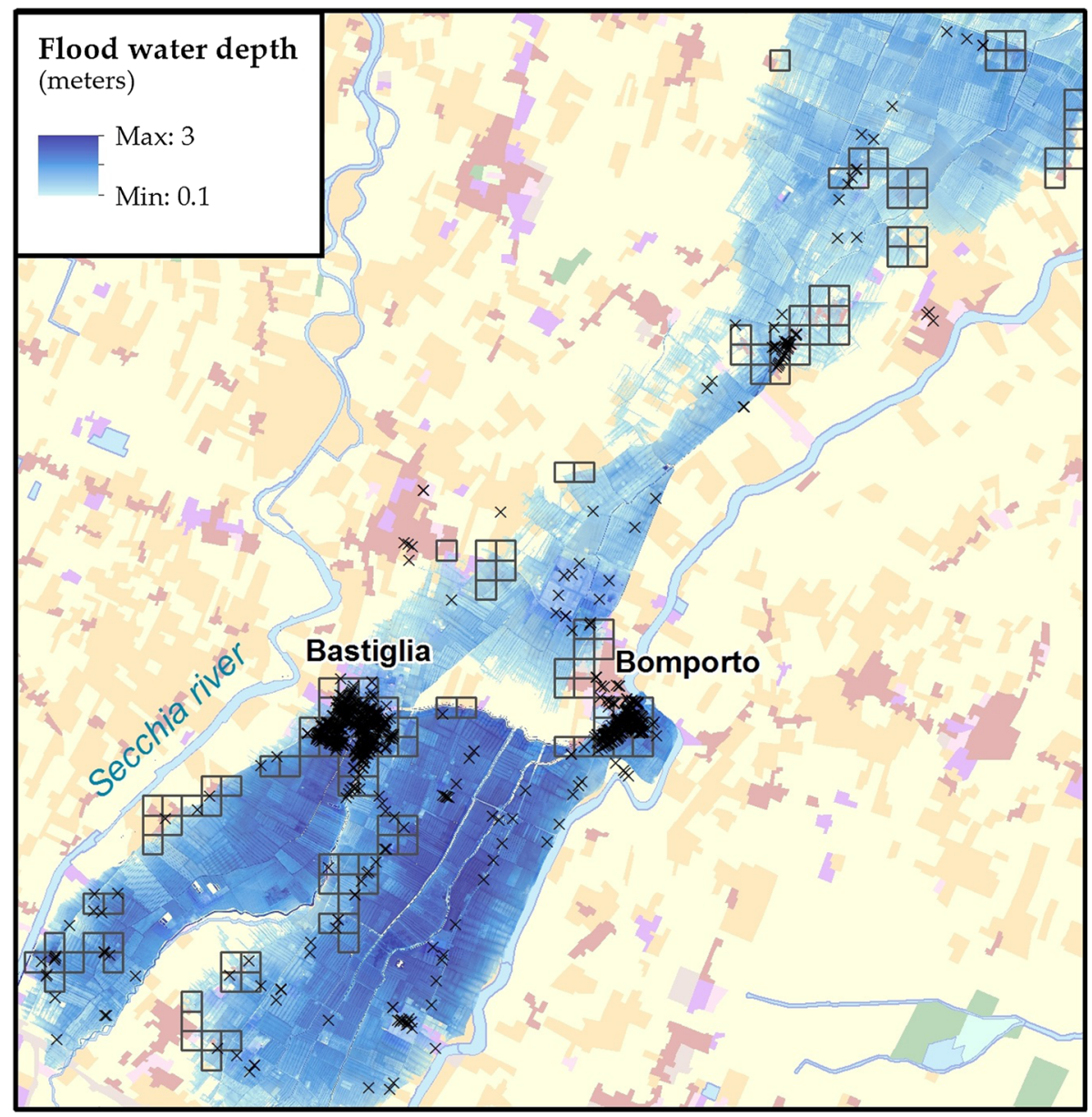

Fig. 6 Location matching for residential land use between empirical (black X) and simulated damage (aggregated to 250 metres cells, as black squares)

wheat crops include all the initial costs, which amount to $50 \%$ of total value. Permanent crops are affected by $20 \%$ of annual production value. The maximum damage (total loss) to crop land estimated from these shares by means of Eq. [2] is 343 euros/ha, less than half compared to the maximum value used by SDC-1 (790 euros/ha). This adjusted maximum value leads to a maximal estimated loss by SDC-1 of 375 thousand euros over 4.2 thousand ha of crop land. Empirical sampling on crop production suggests that the assumption of total loss for exposed crops is over-pessimistic, since crop plants show a good tolerance to inundation (Setti 2014). Overall, an estimate based on case-specific data should be preferred over unadjusted SDC values.

\subsection{Production losses}

The losses are calculated for each economic sector as a share of total annual production. The largest share of damage comes from the industrial sector, affected to the extent of 434 

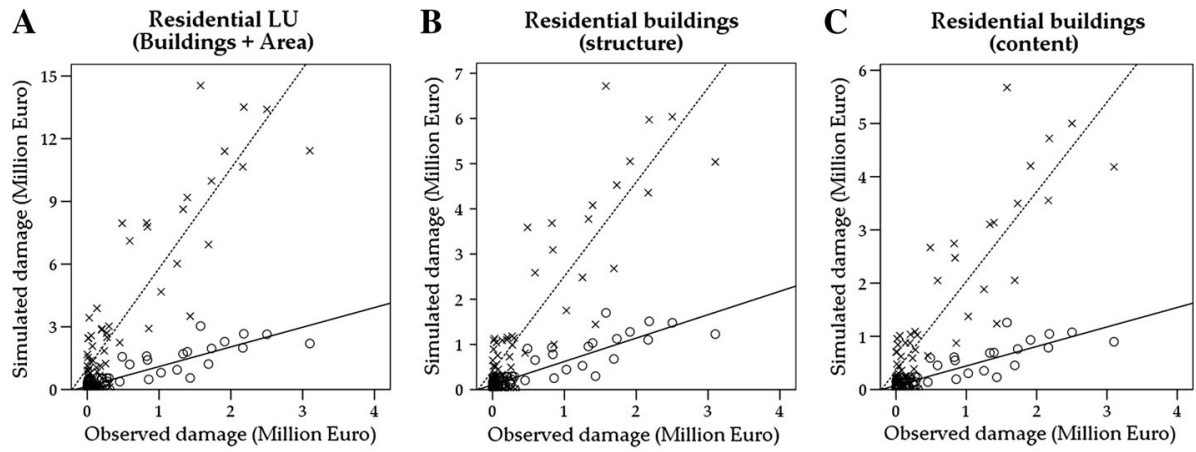

X Pre-calibration SDC output o Post-calibration SDC output

Fig. 7 Scatterplot showing empirical damage (X axis) and SDC results (Y axis) per grid cell using original land use values (cross indicator, dotted line) and calibrated ones (circle indicator, black line) for: a total residential area; b building structure; $\mathbf{c}$ buildings content

Table 1 Exposed area, observed and simulated damage inclusive of regression results for each calibrated land use category tested against empirical data

\begin{tabular}{lclllll}
\hline Land use & & Observed & Simulated & \\
\cline { 1 - 1 } Description & Area $\left(\mathrm{m}^{2}\right)$ & & Damage (million euros) & Damage (million euros) & $R^{2}$ & $B$ \\
\hline Urban area (vehicles) & $1,432,650$ & 5.5 & 2.4 & 0.3 & 0.2 \\
Buildings & 234,950 & 36 & 41.9 & 0.8 & 1.0 \\
Buildings structure & & 22.3 & 24.3 & 0.8 & 1.0 \\
Buildings content & 13.7 & 17.6 & 0.7 & 1.0 \\
Total & $1,667,600$ & 41.5 & 44.4 & 0.8 & 0.9 \\
\hline
\end{tabular}

Table 2 Modelled impact on GVA from the event of Modena 2014

\begin{tabular}{lccl}
\hline & Million euros & Sector $(\%)$ & Total $(\%)$ \\
\hline Agriculture & 9.1 & 6.41 & 0.09 \\
Industry & 434.1 & 14.11 & 4.20 \\
Services & 147.2 & 2.07 & 1.42 \\
Total & 590.4 & & 5.71 \\
\hline
\end{tabular}

million euros, equivalent to $14 \%$ of its annual production (4.2\% of total GVA for the LMAs of Modena, see Table 2). Although the data appear scattered, the ratio between asset damage and annual GVA can shed light on the relationship between structural damage and annual production losses as a function of the flood characteristics (Fig. 8). For a water depth of around one metre, the linear regression (which has an R-squared value of 0.44 ) describes an asset damage close to annual production losses (ratio of 1), approximating the assumptions of the stage-impact curve in Fig. 5. 


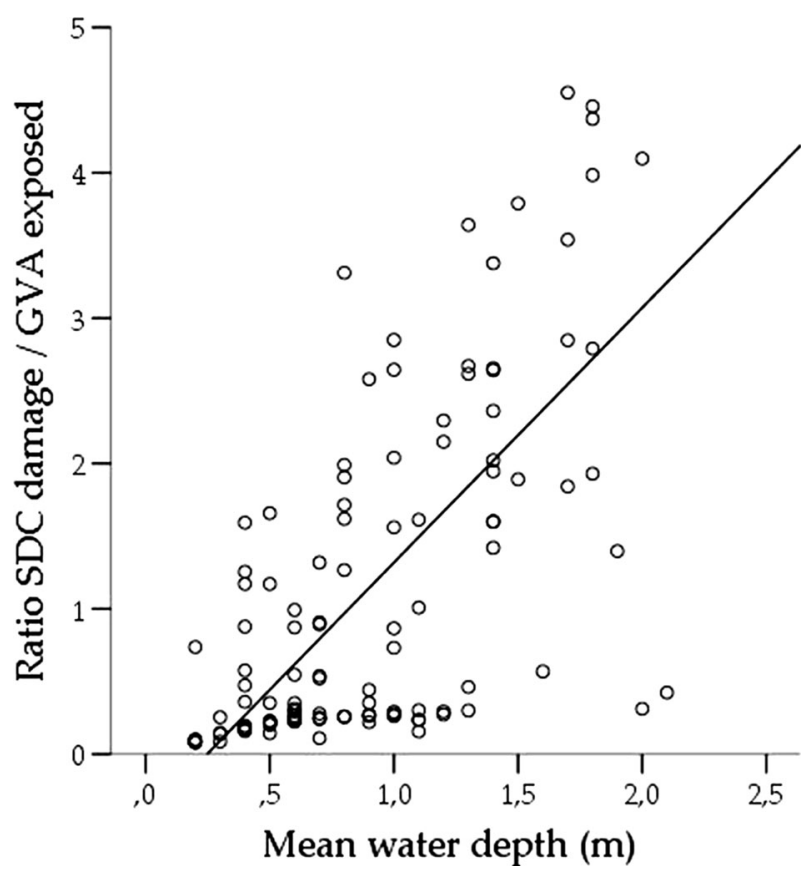

Fig. 8 Scatterplot of mean water depth $(X)$ and ratio of SDC damage over exposed GVA $(Y)$

\subsection{Discussion}

In this paper, we have presented three ways to improve the current state of the art of flood risk assessment models based on the SDC method. Major uncertainties in damage assessments are associated with the value of risk-exposed elements (i.e. maximum damage values) and the depth-damage curves (De Moel and Aerts 2011; Scorzini and Frank 2015). In Sect. 3.1, we have shown that by adjusting the maximum damage values for the specific conditions of the assessment area, the consistency of the model improves substantially. Prior to these adjustments, the tested SDC models overestimated the reported damage by a factor ranging from 4 to 13. After calibration, the maximum damage values for residential buildings are 4-4.5 times smaller than the original values, and the simulation of total damage is very close to empirical observations. These considerations for the Italian territory are consistent with those found by Scorzini and Frank (2015), who likewise stresses the importance of an evidence-based SDC to perform a meaningful flood risk assessment. In Sect. 3.2, we considered the temporal variability in the agricultural sector by using detailed crop yield data and local production patterns. This approach produces a different outcome as compared to the conventional SDC estimate: the maximum crop yield loss per hectare is less than half of what is assumed by SDC-1; likewise, lower damage estimates using a time-dependent approach are found in Forster et al. (2008). Still, our estimate appears to represent a pessimistic scenario compared to available evidence of small to no damage to crop production in our case study. Section 3.3 explains how the GVA approach can approximate output losses within the flooded area with relative ease, if economic data are available. We estimated that the production losses amount to around 600 million euros, or 5.7 per cent of the annual GVA of the Modena LMA. Asset damage appears close to the 
annual GVA when the average water depth reaches one metre; however, these results are hardly comparable to any empirical observations about production losses at the regional scale and thus cannot be properly validated.

\section{Conclusion}

Our analysis aimed at improving flood damage assessment modelling in Italy. The comparison of damage estimates made by SDC models with empirical recorded damage is the key for this task. In this paper, we tested two frequently used SDC models against reported flood damage after a major flood event in Northern Italy. Model calibration has proven useful mainly for improving loss assessment in a specific event area, while it has yet to be ascertained how these calibrated curves can be adjusted for application in surrounding regions. The calibration here is carried out for residential land use categories only, while empirical damage records regarding industrial land use must be analysed to complete the assessment in future research.

Further improvements can be achieved when a larger amount of empirical damage evidence, typically collected by the Civil Protection Agency (CPA), is made accessible to the academic community. Another research thread capable of improving the reliability of flood risk models by reducing the largest uncertainty in the definition of maximum damage values entails spatially disaggregated socioeconomic data such as population, household income and cadastral value of property. With the growing availability of digital spatial data related to these variables, their implementation in an integrated model is an advisable step towards improving the representativeness and reliability of flood risk assessment.

Acknowledgments The research leading to these results received funding from the European Union's Seventh Framework Programme (FP7/2007-2013) under Grant Agreement No 308438 (ENHANCE-Enhancing Risk Management Partnerships For Catastrophic Natural Hazards In Europe). We are grateful to the Department of Civil Engineering, Environment, Territory and Architecture of the University of Parma for providing a flood simulation of the 2014 Modena flood event.

Open Access This article is distributed under the terms of the Creative Commons Attribution 4.0 International License (http://creativecommons.org/licenses/by/4.0/), which permits unrestricted use, distribution, and reproduction in any medium, provided you give appropriate credit to the original author(s) and the source, provide a link to the Creative Commons license, and indicate if changes were made.

\section{References}

Altamura V, Cesena C, Aldo P, Unibo B (2013) Costi di produzione delle principali specie vegetali in Emilia-Romagna 2013. Centro Ricerche Produzioni Vegetali, Regione Emilia-Romagna

Automobile Club Italia (2014) Fringe and benefits table. http://www.aci.it/?id=237. Accessed 3 March 2014 Barredo JI, Engelen G (2010) Land use scenario modeling for flood risk mitigation. Sustainability 2:1327-1344. doi:10.3390/su2051327

Bosello F, Nicholls RJ, Richards J et al (2012) Economic impacts of climate change in Europe: sea-level rise. Clim Change 112:63-81

Carrera L, Standardi G, Bosello F, Mysiak J (2015) Assessing direct and indirect economic impacts of a flood event through the integration of spatial and computable general equilibrium modelling. Environ Model Softw 63:109-122. doi:10.1016/j.envsoft.2014.09.016

Cavallo E, Bank ID, Galiani S, Pantano J (2012) Catastrophic natural disasters and economic growth. InterAmerican Development Bank, Research Department. doi:10.2139/ssrn.1817292

Crichton D (1999) The risk triangle. In: Ingleton J (ed) Natural disaster management. Tudor Rose, London, pp 102-103 
D'Alpaos L, Brath A, Fioravante V (2014) Relazione tecnico-scientifica sulle cause del collasso dell'argine del fiume Secchia avvenuto il giorno 19 gennaio 2014 presso la frazione San Matteo

De Moel H, Aerts JCJH (2011) Effect of uncertainty in land use, damage models and inundation depth on flood risk estimates. Nat Hazards 58:407-425

De Moel H, Asselman NEM, Aerts J (2012) Uncertainty and sensitivity analysis of coastal flood damage estimates in the west of the Netherlands. Nat Hazards Earth Syst Sci 12:1045-1058

De Moel H, van Vliet M, Aerts JCJH (2013) Evaluating the effect of flood damage-reducing measures: a case study of the unembanked area of Rotterdam, the Netherlands. Reg Environ Change. doi:10.1007/ s10113-013-0420-z

De Moel H, Bouwer LM, Aerts JCJH (2014) Uncertainty and sensitivity of flood risk calculations for a dike ring in the south of the Netherlands. Sci Total Environ 473-474:224-234. doi:10.1016/j.scitotenv. 2013.12.015

European Environment Agency (2006) CORINE Land Cover. Version 16 (04/2012). http://www.eea.europa. eu/publications/COR0-landcover. Accessed 14 Feb 2014

Forster S, Kuhlmann B, Lindenschmidt K, Bronstert A (2008) Assessing flood risk for a rural detention area. Nat Hazards Earth Syst Sci 8:311-322

Fotia F (2014) Esondazione del Secchia. http://www.meteoweb.eu/2014/01/esondazione-del-secchiaevacuati-20-milioni-di-metri-cubi-dacqua/255270/. Accessed 29 Aug 2014

Genovese E (2006) A methodological approach to land use-based flood damage assessment in urban areas: Prague case study. Eur. Communities, DG-JRC

Green PC, Viavattene C, Thompson P, Green C (2011) CONHAZ Report-Guidance for assessing flood losses

Hallegatte S (2008) An adaptive regional input-output model and its application to the assessment of the economic cost of Katrina. Risk Anal 28:779-799. doi:10.1111/j.1539-6924.2008.01046.x

Huizinga HJ (2007) Flood damage functions for EU member states. HKV Consultants, Lelystad

ISTAT-Istituto Nazionale di Statistica (2011) $15^{\circ}$ censimento della populazione e delle abitazioni. ISTAT-Istituto Nazionale di Statistica, Rome

ISTAT-Istituto Nazionale di Statistica (2013) Banca dati Italia. http://www.istat.it/it/prodotti/banche-dati. Accessed 14 Feb 2014

Jongman B, Kreibich H, Apel H et al (2012) Comparative flood damage model assessment: towards a European approach. Nat Hazards Earth Syst Sci 12:3733-3752

Klijn F, Baan P, Bruijn K de, Kwadijk J (2007) Overstromingsrisico's in Nederland in een veranderend klimaat

Koks EE, Bockarjova M, De Moel H, Aerts JCJH (2014) Integrated direct and indirect flood risk modeling: development and sensitivity analysis. Risk Anal 35(5):882-900

Kron W (2005) Flood Risk = Hazard $\times$ Values $\times$ Vulnerability. Water Int 30:58-68. doi:10.1080/ 02508060508691837

Luino F, Cirio CG, Biddoccu M et al (2009) Application of a model to the evaluation of flood damage. Geoinformatica 13:339-353. doi:10.1007/s10707-008-0070-3

Merz B, Kreibich H, Schwarze R, Thieken A (2010) Assessment of economic flood damage. Nat Hazards Earth Syst Sci 10:1697-1724. doi:10.5194/nhess-10-1697-2010

Messner F, Penning-rowsell E, Green C, et al (2007) Evaluating flood damages: guidance and recommendations on principles and methods. FLOODsite Integrated Flood Risk Analysis and Management Methodologies. HR Wallingford, UK

Meyer V, Becker N, Markantonis V et al (2013) Review article: assessing the costs of natural hazards-state of the art and knowledge gaps. Nat Hazards Earth Syst Sci 13:1351-1373. doi:10.5194/nhess-13-13512013

Molinari D, Aronica GT, Ballio F, et al (2013) Le curve di danno quale strumento a supporto della direttiva alluvioni: criticità dei dati italiani, pp 10-15

Osservatorio Agro-Alimentare Emilia Romagna (2014) Il sistema agro-alimentare dell'Emilia-Romagna

Peduzzi P, Dao H, Herold C, Mouton F (2009) Assessing global exposure and vulnerability towards natural hazards: the Disaster Risk Index. Nat Hazards Earth Syst Sci 9:1149-1159. doi:10.5194/nhess-9-11492009

Przyluski V, Hallegatte S (2011) Indirect costs of natural hazards-CONHAZ report

Regione Emilia-Romagna (2011) Coperture vettoriali dell'uso del suolo 2008. http://servizigis.regione. emilia-romagna.it/ctwmetadatiRER/metadatoISO.ejb?stato_IdMetadato=iOrg01iEnP1idMetadato76868. Accessed 1 Jul 2015

Rose A (2004) Defining and measuring resilience to disasters. Disaster Prev Manag 13:307-314

Rose A, Wei D (2013) Estimating the economic consequences of a port shutdown: the special role of resilience. Econ Syst Res 25:212-232. doi:10.1080/09535314.2012.731379 
Saint-Geours N, Bailly J-S, Grelot F, Lavergne C (2014) Multi-scale spatial sensitivity analysis of a model for economic appraisal of flood risk management policies. Environ Model Softw 60:153-166. doi:10. 1016/j.envsoft.2014.06

Sargent DM (2013) Updating residential flood stage-damage curves based on building cost data. Reach. out to Reg.-SIAQ Conf

Scorzini A, Frank E (2015) Flood damage curves: new insights from the 2010 flood in Veneto, Italy. J Flood Risk Manage. doi:10.1111/jfr3.12163

Setti G (2014) Recuperare i suoli dopo l'alluvione. Terra e vita 11

Sluijs L, Snuverink M, van den Berg K, Wiertz A (2000) Schadecurves industrie ten gevolge van overstroming. Tebodin Consultant, RWS DWW, Den Haag

Tapia-Silva F-O, Itzerott S, Foerster S et al (2011) Estimation of flood losses to agricultural crops using remote sensing. Phys Chem Earth Parts A/B/C 36:253-265

Thieken AH, Ackermann V, Elmer F, et al (2009) Methods for the evaluation of direct and indirect flood losses. RIMAX Contributions at the 4th International Symposium on Flood Defence, pp 1-10

Twining S (2014) Impact of 2014 Winter floods on agriculture in England. ADAS UK ltd

Ward PJ, Jongman B, Weiland FS et al (2013) Assessing flood risk at the global scale: model setup, results, and sensitivity. Environ Res Lett 8:044019. doi:10.1088/1748-9326/8/4/044019

Winsemius HC, Van Beek LPH, Jongman B et al (2013) A framework for global river flood risk assessments. Hydrol Earth Syst Sci 17:1871-1892. doi:10.5194/hess-17-1871-2013 